\title{
Czechy, Słowacja i Czechosłowacja - geografia regionalna dawniej i dziś
}

\section{Zlecenie sprzed 30 lat}

Profesor Ludwik Straszewicz zaproponował mi w roku 1985 napisanie regionalnej monografii o Czechosłowacji, podobną do tych, które on sam napisał dla wydawnictwa PWN. Były to znane wówczas dobrze geograficzne opisy Francji (Straszewicz 1972), Włoch (Straszewicz 1977) i Hiszpanii (Straszewicz 1982).

Dla trzydziestoletniego doktoranta z Uniwersytetu Karola w Pradze była to pierwsza propozycja publikacji tej rangi i dlatego bardzo się tym przejąłem. W pierwszej chwili nawet zacząłem się zastanawiać, czy dam radę, ale bardzo szybko doszedłem do wniosku, że propozycja profesora bynajmniej nie jest pochopna. Profesor wiedział, że jestem Polakiem z Zaolzia w Czechosłowacji i przez całe życie tam mieszkam. Jestem polsko-czesko dwujęzyczny, a po studiach geografii w Bratysławie nieobcy mi jest także język słowacki. Ponadto znałem już wtedy dość dobrze środowisko geografów i w Czechosłowacji, i w Polsce, rozumiałem drobne różnice $\mathrm{w}$ pojmowaniu geografii w obydwu krajach. Dziś wiem, że byłem w tym czasie odpowiednim kandydatem do napisania monografii Czechosłowacji dla polskich czytelników i podziwiam profesora, że to bezbłędnie rozpoznał. Do realizacji tego pomysłu jednak nie doszło. Geograficzna monografia o Czechosłowacji nie powstała.

Minęło trzydzieści lat i dziś sam jestem profesorem, podczas kiedy profesora Straszewicza między nami już nie ma. Gdyby tu był, miałby sto lat. Chętnie bym z nim dziś porozmawiał i na pewno podjąbym temat jego dawnego zlecenia. Jestem przekonany, że interesowałoby go, jak wygląda Czechosłowacja dziś, a raczej jak wygląda obszar, który to nieistniejące już państwo zajmowało. Na pewno porozmawialibyśmy również o tym, jak by dzisiaj wyglądała realizacja tego zadania. A więc nie tylko, co się zmieniło na badanym obszarze: że Czechosłowacja podzieliła się 
na dwa kraje i trzeba dziś opisać każdy z nich z osobna. Musielibyśmy się zająć tym, jak by dziś taka regionalna monografia wyglądała, uwzględniając stan dzisiejszej geografii.

Ponieważ rozmowa z profesorem nie jest dziś możliwa, z okazji setnej rocznicy jego urodzin postanowiłem spróbować opisać jej prawdopodobne elementy i przelać je na papier. $W$ ten sposób powstał niniejszy tekst.

\section{Co się zmieniło na terytorium byłej Czechosłowacji}

\section{Rozpad Czechosłowacji}

Rozpad Czechosłowacji w latach 1992-1993 był dla wielu zaskoczeniem, i to nawet dla geografów, którzy ten kraj dobrze znali. Przyjrzawszy się lepiej, można było jednak zauważyć, że Czechosłowacja miała w sobie od początku zakodowany podział wewnętrzny, który miał potencjał rozsadzenia tego państwa. Pierwszy rozpad Czechosłowacji, na krótko przed II wojną światową w marcu 1939 r., nie był więc wyłącznie wynikiem niekorzystnej sytuacji międzynarodowej. W monografii o Czechosłowacji byłby to na pewno ważny element, należałoby podkreślić, że nie ma i nie było Czechosłowaków, ale są Czesi i Słowacy, zamiesz-

164 kujący odrębne terytoria i do tego niezbyt terytorialnie wymieszani, oddzieleni wyraźna, przez wieki niezmieniającą się granica, choć miała ona wówczas tylko charakter granicy administracyjnej.

Podział zarysował się formalnie w roku 1969, kiedy Czechosłowacja przekształciła się w państwo federacyjne, składające się z dwu republik: czeskiej i słowackiej. Republiki miały formalnie znaczną niezależność, $\mathrm{w}$ praktyce jednak istotnie ograniczoną poprzez fakt, że najważniejsze decyzje zapadały w organach rządzącej wówczas partii komunistycznej. Skomplikowana struktura władzy miała zapewnić równoprawną pozycję obydwu republikom, co było ważne zwłaszcza dla Słowaków, których było mniej ( $5 \mathrm{mln}$ na $10 \mathrm{mln}$ Czechów). Brak praktyki demokratycznego zarządzania był powodem tego, że wszelka dyskusja na temat zmian we wzajemnych stosunkach była zupełnie niemożliwa i dlatego nikt nie był do niej przygotowany. Tego nie planowałem opisywać w swojej książce, ale na to zwróciłbym uwagę dziś, bo uważam, że brak doświadczenia $\mathrm{w}$ demokratycznej dyskusji był jedną z istotnych przyczyn podziału (Siwek 2004).

Po upadku komunizmu w roku 1989 totalitarna przeszkoda demokratycznej dyskusji zniknęła, co przejawiło się wkrótce w wyartykułowaniu odmiennych poglądów Czechów i Słowaków na to, jak powinien się dalej rozwijać ich kraj. Podczas kiedy Czesi uważali, że najważniejsza jest w danej chwili demokratyzacja i przemiany ekonomiczne, Słowakom chodziło 
o lepsze ułożenie wzajemnych stosunków. Czesi tego nie rozumieli. Jako większy naród w federacji utożsamiali się z nią jako z całością i animozje na tle narodowościowym uważali za małostkowe czy też przestarzałe. Dla Słowaków, jako tych mniejszych, było to jednak bardzo ważne, bo nikt nie lubi w żadnym związku być słabszym.

Wyłonione w pierwszych demokratycznych wyborach w roku 1990 polityczne reprezentacje Czechów i Słowaków pomimo początkowej euforii z wyzwolenia się spod komunistycznej władzy totalitarnej zaczęły wkrótce zmierzać $\mathrm{w}$ innych kierunkach. Czesi szli w kierunku liberalno-prawicowym, Słowacy $\mathrm{w}$ kierunku narodowościowo-lewicowym. Drugie wybory w czerwcu $1992 \mathrm{r}$. te zarysowujące się zaraz po upadku komunizmu różnice jeszcze bardziej uwypukliły. Rozpoczął się nowy cykl rozmów o zmianach w ułożeniu wzajemnych stosunków, który jednak doprowadził szybko do obustronnego zrozumienia, że podział jest nieuchronny. Walnie przyczynili się do tego obaj główni negocjatorzy, premierzy rządów regionalnych: czeski Václav Klaus i słowacki Vladimír Mečiar, których ambicje osobiste nie pozostawiały żadnego miejsca na kompromis. Nie zdecydowali się na rozpisanie referendum, choć przy tak ważnej kwestii można się było tego spodziewać. Referendum prawdopodobnie przesądziło by o podziale - co najmniej na Słowacji - ale jego nie zrealizowanie daje do dziś zwolennikom jednolitej Czechosłowacji argument, że mogło jedność kraju uratować.

25 listopada 1992 r. parlament federalny Czechosłowacji zaakceptował decyzję rządów narodowych i przyjął ustawę o zaniku państwa w dniu 31 grudnia 1992 r. Parlamenty regionalne w międzyczasie przyjęły konstytucje nowych państw a 1 stycznia 1993 r. rządy regionalne Czech i Słowacji przejęły rolę rządów nowych państw: Republiki Czeskiej i Republiki Słowackiej.

\section{Czechy}

Geografa regionalnego, jakim był Ludwik Straszewicz, na pewno by interesowała Republika Czeska głównie pod kątem porównania jej z byłą Czechosłowacją. Jako większe z obydwu państw-spadkobierców Republiki Czechosłowackiej i z jej dawną stolicą Pragą ma większe szanse na utożsamienie z nią aniżeli mniejsza Słowacja. W Republice Czeskiej na powierzchni 78 tys. $\mathrm{km}^{2}$ (61\% terytorium Czechosłowacji) mieszka dziś 10,5 mln mieszkańców (66\% ludności Czechosłowacji). Absolutna liczba mieszkańców jest tylko niewiele większa niż 30 lat temu (10,3 mln w roku 1980). Stolicą pozostała Praga, której liczba mieszkańców (1,2 mln) też jest tylko nieznacznie wyższa od liczby mieszkańców odnotowanej w latach 80. Po podziale federacji jest jednak stolicą wyrośniętą wyraźnie ponad 
potrzeby 10-milionowego państwa i jest świadectwem tego, że była kiedyś stolicą większego kraju. To sytuacja podobna do tej, w której znajdują się m.in. Wiedeń lub Budapeszt. Lista największych miast czeskich jest podobna do tej z lat 80., a liczba ich mieszkańców nie przekracza dzięki suburbanizacji i zmniejszenia przyrostu naturalnego ówczesnego poziomu. Niektóre miasta są nawet wyraźnie mniejsze - zwłaszcza te, które w przeszłości rozwinęły się dzięki przemysłowi. Najwyraźniej zmniejszyła się Ostrava, trzecie miasto kraju i duży ośrodek przemysłowy oparty na wydobyciu węgla i produkcji stali. Od połowy lat 80. miasto zmniejszyło się z 320 tys. do 295 tys. mieszkańców i jest najbardziej jaskrawym przykładem procesu „kurczenia się“ miasta (Rumpel, Siwek, Slach 2014).

Czechy są tak jak dawniej krajem narodowościowo homogenicznym. $\mathrm{W}$ ostatnich trzech dekadach odnotowano wprawdzie dzięki otwarciu kraju na świat wzrost liczby cudzoziemców do ok. 0,5 mln w roku 2015 ( $5 \%$ z wszystkich mieszkańców kraju), ale w porównaniu z krajami Europy zachodniej to bardzo niski udział. Zmiany składu etnicznego odnotowano jednak także wśród ludności rodzimej, która ma obywatelstwo Republiki Czeskiej. W latach 90. pojawił się bowiem fenomen deklarowania tożsamości regionalnych jako narodowości. Byli to głównie Morawianie, którzy w wyborach uzyskali legalną reprezentację polityczną i masowo 166 deklarowali narodowość morawską: w roku 1991 było ich 1,3 mln, tzn. 30\% ludności historycznych Moraw. Pojawiła sią także narodowość śląska, ale w porównaniu z sytuację w Polsce 10 lat później, miała minimalne znaczenie. Narodowość śląską zadeklarował zaledwie ułamek procenta (Siwek 2002). Liczba zdeklarowanych Morawian w kolejnym spisie ludności w roku 2001 wprawdzie zmalała do jednej trzeciej, ale w roku 2011 znowu wzrosła do 0,5 mln Zupełnie nowym zjawiskiem było zignorowanie pytania o narodowość przez 25\% mieszkańców Czech w spisie roku 2011. Narodowość i religia zostały od roku 2001 zaszeregowane do kategorii dobrowolnych, ale dopiero w ostatnim spisie ludność masowo odmawiała udzielić odpowiedzi na to pytanie. Była to prawdopodobnie $\mathrm{w}$ pewnym sensie demonstracja oporu przeciwko samej instytucji spisu ludności, postrzeganego jako niedopuszczalna ingerencja władz w sferę prywatną. Niewykluczone jednak, że jest to zwiastunem nowego podejścia do narodowości w sensie etnicznym, która przestaje być istotnym wyróżnikiem dla wielu współczesnych ludzi.

Ciekawy rozwój przyniosły też zmiany w składzie religijnym Czech. W okresie komunistycznym przynależności religijnej w spisach z zasady nie badano a same kościoły były w społeczeństwie odsuwane na margines. Dopiero w roku 1991 można było ponownie zadeklarować przynależność religijną i zrobiło to 43,9\% ówczesnych Czechów. Pomimo braku jakichkolwiek negatywnych ingerencji władz aż 16\% z nich nie odpowie- 
działo na to pytanie - pomimo tego, że było wówczas jeszcze obowiązkowe. Tak duży odsetek braku odpowiedzi był interpretowany, jako kontynuacja obaw ludzi wierzących z ewentualnych prześladowań, które były ich udziałem w okresie władzy komunistycznej. W kolejnych spisach ludności z lat 2001 i 2011 okazało się jednak, że było inaczej. Przynależności religijnej w roku 1991 nie podały osoby, które czuły, że obecnie wypada się zadeklarować, ale już się tak oddaliły od kościoła, że nie miały niczego do zadeklarowania. W tym miejscu należy wyjaśnić, że większość Czechów już od kilkudziesięciu lat nie chrzci swoich dzieci, nie zawiera ślubów w kościele ani nie robi kościelnych pogrzebów. Kolejne czeskie spisy ludności wykazały, że liczba ludzi unikających odpowiedzi na pytanie o religię zmalała, ale nie przybyło dzięki temu wierzących. Najbardziej wzrosła grupa niewierzących. Wg ostatniego spisu ludności Republika Czeska jest jednym z najbardziej zlaicyzowanych społeczeństw w Europie. Tylko 14,0\% z ogółu mieszkańców zadeklarowało przynależność do jednego z działających w Czechach kościołów - większość z nich do kościoła katolickiego. Ponadto 6,8\% Czechów określiło się jako osoby wierzące, ale nieprzynależące do żadnego kościoła. To też ciekawy i niewystępujący $\mathrm{w}$ innych krajach fenomen struktury religijnej. Regionalnie występuje wyraźny podział na bardziej ateistyczny północny-zachód (Czechy właściwe) i względnie religijny południowy wschód (Morawy i część czeskiego Śląska) (Siwek 2005).

Od upadku komunizmu na terenie państwa czeskiego doszło do zmian w strukturze zatrudnienia i wykształcenia. Zmniejszyła się liczba pracowników w rolnictwie i w przemyśle na rzecz sektora usług. Zmalała liczba robotników. Dzięki powstaniu kilku nowych uniwersytetów, a od roku 2000 również wyższych szkół prywatnych, radykalnie wzrosły możliwości studiowania i znacznie wzrósł odsetek ludności z ukończonym wykształceniem wyższym liczonym z ludności powyżej 15 roku życia: z 5,0\% w roku 1980 do 12,5\% w roku 2011.

Duże zmiany w porównaniu z okresem komunistycznym zaszły w gospodarce. Przemysł ciężki przestał być chlubą gospodarki Czech. Zagłębie Ostrawsko-Karwińskie ograniczyło wydobycie węgla kamiennego do połowy, mniejsze zagłębia przeszły do historii (Kladno, Žacléř-Svatoňovice, Rosice-Oslavany). Wydobycie węgla brunatnego też jest o wiele mniejsze niż w latach 80. Firmy wydobywcze dziś z trudem przełamują opór ekologów i niechętnej im opinii publicznej. Energetyka wykorzystuje dziś rozmaite źródła energii - łącznie z jądrowa, która jest też solą w oku organizacji ekologicznych oraz sąsiedniej Austrii. W ostatniej dekadzie dzięki rządowemu wsparciu znacznie się powiększyła energetyka ze źródeł odnawialnych (elektrownie słoneczne), choć na razie nie jest to rozwiązanie korzystne z ekonomicznego punktu widzenia. Przemysł maszynowy, który 
był dobrze rozwinięty już w czasach Austro-Węgier, jeszcze bardziej się rozwinął głównie dzięki firmom samochodowym: czeska marka Škoda z fabryką w mieście Mladá Boleslav weszła do koncernu Volkswagen, powstały nowe fabryki TPCA (Toyota-Peugeot-Citröen) w Kolínie oraz koreański Hyundai w Nošovicach koło miasta Frýdek-Místek.

Przemysł lekki, głównie tekstylny i odzieżowy, nawet po prywatyzacji nie wytrzymał konkurencji z Azji. Produkcja papieru i celulozy pozostała na marginesie. Przemysł spożywczy jest bardzo zróżnicowany: niektóre firmy upadły, niektóre przetrwały transformację, niektóre nowe powstały. Do wielu z nich wszedł kapitał zagraniczny: np. do browarów (np. Pilzner, Radegast, Braník), do produkcji wód mineralnych (Mattoni) $\mathrm{i}$ in. Produkcja wina przeważnie na Morawach południowych ma lokalne znaczenie.

Rolnictwo ma do dyspozycji 4,2 mln ha i nadal produkuje typowe dla tego regionu płody rolne: zboża, ziemniaki, buraki cukrowe, chmiel. Hodowla bydła ma mniejsze znaczenie. Generalnie produkcja rolna jednak maleje i w kontekście europejskim Republika Czeska zajmuje odległe miejsce $\mathrm{w}$ wartości produkcji rolnej w przeliczeniu na mieszkańca: 78\% średniej europejskiej. W produkcji warzyw Czechy znajdują się na przedostatnim miejscu w UE. W ostatnich latach powiększyła się natomiast po168 wierzchnia uprawy rzepaku, który w znacznej części służy do produkcji dodatku do paliwa.

Radykalnie zmieniła się struktura własnościowa ziemi rolnej. Z prawie $100 \%$ uspołecznienia do prawie $100 \%$ prywatyzacji. Tak to wygląda w statystyce, ale w rzeczywistości została zachowana większość ogromnych przymusowo scalonych w okresie komunistycznym gospodarstw. Unicestwiona warstwa chłopska się nie odrodziła. Potomkowie dawnych gospodarzy (często żyjący już $\mathrm{w}$ miastach) w procesie reprywatyzacji odebrali pola, należące kiedyś do ich przodków, ale rzadko decydowali się naprawdę na nich gospodarować. Przeważnie od razu oddawali je $\mathrm{w}$ dzierżawę firmom, które powstały z przetransformowanych dawnych spółdzielni rolnych. W ten sposób Czechy są dziś krajem o jednej z największych średnich powierzchni gospodarstw rolnych w Europie (89,3 ha wobec średniej w UE na poziomie 22 ha).

Komunikacja w ostatnich trzech dekadach bardzo się rozwinęła. Sieć autostrad, budowana już od lat 70., jest ciaggle poszerzana, choć nie tak szybko, jak by tego wymagała sytuacja. Jej długość wynosi obecnie 795 km, do tego dochodzi $439 \mathrm{~km}$ dróg ekspresowych. W roku 1985 było na terenie dzisiejszej Republiki Czeskiej tylko niecałych $300 \mathrm{~km}$ autostrad. Zmieniły się też preferencje kierunków rozwoju sieci komunikacyjnych. Podczas kiedy w latach 80 Czesi koncentrowali się na połączeniach wewnętrznych (autostrada Praga - Brno - Bratysława) i na kontaktach w kie- 
runku wschodnim, od roku 1990 buduje się przede wszystkim połączenia na zachód: autostrada z Pragi przez Pilzno nawiązuje na niemiecką sieć autostrad w kierunku Norymbergi i Paryża, w kierunku Drezna i Berlina brakuje już tylko jednego odcinka.

Sieć kolei czeskich stagnuje a nawet nieznacznie się kurczy. Od lat 90. zamknięto dla ruchu osobowego niektóre peryferyjne, słabo wykorzystywane linie. Niektóre odkupiły podmioty prywatne, najczęściej stowarzyszenia regionalne lub ekologiczne, które eksploatują je bardziej z powodów nostalgicznych lub ekologicznych niż ekonomicznych. W porównaniu z innymi krajami - np. ze Słowacją - zamkniętych odcinków kolei nie jest zbyt wiele i Republika Czeska pozostaje krajem o jednej z najgęstszych sieci kolejowych na świecie $\left(12,1 \mathrm{~km}\right.$ kolei na $100 \mathrm{~km}^{2}$ powierzchni kraju, ponad dwukrotnie wyższa od średniej w UE, wynoszącej 5,6 km kolei na $100 \mathrm{~km}^{2}$ ). Główne korytarze kolejowe, łączące największe miasta czeskie, zostały w ostatnich 2 dekadach zmodernizowane. Oprócz państwowych Kolei Czeskich obsługę pasażerów zapewniają również dwa konkurencyjne przedsiębiorstwa prywatne: RegioJet (2010) i Leo Express (2012). Konkurencja poprawiła jakość usług transportowych na głównej trasie Praga - Ostrawa. Od roku 2005 kursują na niej znane również w Polsce włoskie składy Pendolino. Spowodowało to zahamowanie tendencji spadku liczby podróżnych i ich ponowny wzrost w ostatnich 10 latach.

Transport lotniczy od lat 80. zwielokrotnił swoje przewozy. Korzystanie $\mathrm{z}$ transportu lotniczego jest dziś osiągalne nawet dla przeciętnego Czecha z jednej strony dzięki obniżeniu kosztów lotów a z drugiej dzięki otwarciu granic. Na rynku czeskim działają obecnie znane światowe linie lotnicze tak samo, jak tani przewoźnicy. Czeska część Czechosłowackich Linii Lotniczych ukonstytuowała się pod nazwą Czeskie Linie Lotnicze, które działają w konsorcjum Sky Team (z Air France, KLM, Delta i in.). Są to jednak linie małe, i mają problemy finansowe. Ze względu na wielkość kraju tylko jedno lotnisko ma charakter pełnowymiarowego międzynarodowego portu lotniczego: lotnisko Václava Havla w Pradze. Lotniska w Brnie, w Ostrawie i w Karlovych Varach mają lokalny charakter i służą najwyżej dla lotów czarterowych w sezonie turystycznym lub jako lotniska zapasowe.

Podsumowując można stwierdzić, że czeska część dawnej Czechosłowacji rozwija się zgodnie z tradycjami, ukształtowanymi na tym terenie już w przeszłości. Postrzegana jest najczęściej jako kontynuatorka Czechosłowacji, tyle że geograficznie mniejsza i o mniejszym znaczeniu gospodarczym i geopolitycznym. Wg danych Banku Światowego poziom czeskiego PKB w roku $2011 \mathrm{w}$ wysokości 26 tys. USD dawał Czechom 19 miejsce w Europie i 36 w świecie. Dokładnego porównania z okresem rządów partii komunistycznej nie można przeprowadzić z powodu 
nieprzystosowalności komunistycznego systemu gospodarczego do reguł gospodarki rynkowej i niechęci ówczesnych władz publikowania nawet przybliżonych szacunków na ten temat, ponieważ kraje tzw. „demokracji ludowej" wypadłyby słabo.

Gwarancję bezpieczeństwa dają jej struktury organizacji NATO, w której jest od roku 2004 a ekonomicznie chroni ją Unia Europejska. Trzeba tu jednak zaznaczyć, że dawna euforia z przynależności do Zachodu przez duże Z już się ulotniła. Dzięki niektórym eurosceptycznym politykom, przede wszystkim prezydentowi Klausowi (2003-2013), większość Czechów akcentuje swój dystans wobec wyżej wymienionych struktur wojskowych i gospodarczych. Czesi nie przyjęli na razie euro, choć przystępując do Unii zadeklarowali chęć jego przyjęcia. Na razie decyzja ta jest odsuwana na później (podobnie ja w Polsce), a w dyskursie publicznym pojawiają się głosy domagające się unieważnienia tego zobowiązania. Aktualny kryzys gospodarczy i problemy zadłużenia niektórych krajów UE (np. Grecji) powodują wzmocnienie tych nastrojów. Póki co, Republika Czeska pozostaje członkiem NATO i UE i ani aktualnie rządząca koalicja (Czeska Partia Socjaldemokratyczna z populistycznym ruchem „Ano“ i z partią ludową) ani opozycja (prawicowe partie Obywatelska Partia Demokratyczna i TOP 09) nie postulują zmian w tym punkcie. Przeciw struk-

170 turom europejskim i strukturom NATO są tylko czescy komuniści (jedna z niewielu partii z Europy środkowej i wschodniej, która działa pod starą nazwą), którzy mają swoją reprezentację w parlamencie, ale ich potencjał koalicyjny jest zerowy, więc nic nie wskazuje na to, żeby mogli w najbliższej przyszłości mieć jakikolwiek wpływ na kierunek czeskiej polityki zagranicznej (Morawiec 2008).

Stosunek Czechów do Słowacji po 20 latach jest bardzo dobry. W Czechach pracują liczni słowaccy artyści, trenerzy, biznes prowadzą przedsiębiorcy. Słowaków można spotkać na wszystkich szczeblach społecznej hierarchii - nawet wśród czeskich ministrów. Obecnym ministrem finansów jest m.in. Słowak Andrej Babiš, jeden ze znaczniejszych przedsiębiorców w Republice Czeskiej. Słowacy w tak wysokich funkcjach mają najczęściej obywatelstwo czeskie, choć niekoniecznie. Ewenementem był minister transportu przejściowego rządu "technicznego“ premiera Jana Fischera (2009-2010) Gustav Slamečka, który z wnioskiem o czeskie obywatelstwo wystapił dopiero po otrzymaniu dekretu nominacyjnego.

Obywatele Słowacji mogą pracować i uczyć się w Republice Czeskiej na tych samych zasadach jak obywatele czescy. Ponieważ obydwa języki są bliskie, na wszystkich stanowiskach pracy, na których wymagana jest znajomość czeskiego, wystarczy znać słowacki. Tysiące Słowaków korzysta z tych możliwości i podejmuje pracę, lub studiuje w Czechach. Ze względu na niższy poziom płac na Słowacji, jest to dla nich z reguły 
korzystne finansowo. W Czechach są nieformalnie traktowani jak "swoi“. Dobrym przykładem tego są imprezy sportowe i kulturalne. Czescy kibice wspierają słowackie drużyny, o ile rywalizują z krajami trzecimi. Na występy słowackich artystów i zespołów czescy widzowie chodzą częściej i chętniej aniżeli na występy jakichkolwiek innych cudzoziemców.

W polityce obie strony określają wzajemne stosunki jako bardzo dobre i w porównaniu z wszystkimi pozostałymi nadstandartowe. Nowo wybrani czescy prezydenci jako cel swojego pierwszego wyjazdu zagranicznego wybierają zawsze Słowację a od kilku lat organizowane są nawet raz w roku wspólne posiedzenia rządów. Negatywne zjawiska we wzajemnych relacjach występują minimalnie, a nawet jeżeli pomimo wszystko coś się zdarzy, chodzi z reguły o błahą sprawę.

\section{Słowacja}

Geograf regionalny pokroju Ludwika Straszewicza na pewno przyjrzałby się Słowacji jeszcze uważniej aniżeli Czechom. Najprawdopodobniej dlatego, że Słowacja ma o wiele więcej znamion nowego państwa aniżeli Republika Czeska, która na mapach mentalnych jest częściej postrzegana jako kontynuatorka dawnej Czechosłowacji.

Początek samodzielności nie był dla Słowacji łatwy. Sytuacja polityczna i ekonomiczna na Słowacji zdawała się w pierwszych latach niepodległości potwierdzać pesymistyczne oczekiwania, że mały kraj ma o wiele mniejsze szanse na sukces niż większy. Gospodarka zaczęła od razu wykazywać znamiona kryzysu a sytuacja polityczna wcale nie była lepsza. Autokratyczny premier Mečiar wprowadził Słowację do częściowej międzynarodowej izolacji. Słowacja nie została przyjęta do NATO razem z Polską i Czechami, lecz dopiero w roku 2004. Do Unii Europejskiej, weszła już jednak razem z nimi 1 maja 2004 roku.

Po roku 2000 Słowacja zaczęła jednak sobie radzić. Mečiar po przegranych wyborach $\mathrm{w}$ roku 1998 znalazł się w opozycji i z czasem zniknął ze sceny politycznej. Rządy chrześcijańskich demokratów i ich koalicjantów premierów Mikuláša Dzurindy (1998-2006) oraz Ivety Radičovej (2010-2012) skierowały Słowację na kurs wybitnie proeuropejski. Zaowocowało to m.in. przyjęciem waluty euro już w roku 2009. I nic w tej kwestii nie zmienił nawet obecny lewicowy rząd nieco populistycznego premiera Roberta Fica (Gniazdowski 2008).

Liczba mieszkańców Słowacji (5,4 mln) jest tylko nieznacznie wyższa od liczby mieszkańców tego obszaru przed podziałem Czechosłowacji. Skład narodowościowy rodzimej ludności jest podobny do tego, jaki tu był dawniej: mniej homogeniczny od Czech (duża mniejszość węgierska i romska, po ok. 5-7 \% każda i mniej liczne mniejszości: rusińska, 
ukraińska, czeska i in.), ale z minimalną liczbą nowych imigrantów z zagranicy (77 tys. osób w roku 2014, tzn. 1,4\% ogółu mieszkańców, 2/3 z nich są obywatelami któregoś z krajów UE, najczęściej bezpośrednich sąsiadów Słowacji). Okazuje się, że Słowacja nie jest atrakcyjnym celem migracji nawet w obecnym okresie ich rosnącego globalnego natężenia. Podczas ostatniego spisu nie wystąpiło tu też zjawisko masowego unikania deklarowania narodowości. Dotyczyło tylko 8\% przypadków, skala tego zjawiska jest więc czterokrotnie niższa, aniżeli w Czechach.

Słowacja nie jest tak zurbanizowana, jak Czechy. W miastach mieszka mniejszy odsetek ludności (57\% wg ostatniego spisu ludności w roku 2011) niż w Czechach i miasta te są generalnie mniejsze. Stolica Bratysława ma 0,5 mln mieszkańców, a rolę metropolii utrudnia jej w pewnym sensie niekorzystne położenie: jest miastem granicznym na trójstyku Słowacji, Austrii i Węgier. Z drugiej strony jako miasto nad Dunajem znakomicie wkomponowuje się w układ tworzony przez Wiedeń i Budapeszt. To, co jest niekorzystne dla wewnętrznego układu osadniczego, okazuje się atutem z punktu widzenia kontaktów zagranicznych i procesów integracyjnych w Unii Europejskiej. Z pozostałych miast słowackich na uwage zasługują już tylko Koszyce na wschodzie kraju (200 tys. mieszkańców). Pozostałe miasta ledwo sięgają granicy 100 tys. mieszkańców: Prešov, Ni172 tra, Banská Bystrica i Žilina.

Struktura ludności - diametralnie odmienna od czeskiej - jeszcze na początku XX w., w czasach wspólnego państwa z Czechami dosyć się upodobniła do struktury przeważającej w Czechach pod względem wykształcenia i struktury zawodowej. Słowacy w okresie 1918-1992 przeszli od pracy na roli do pracy w przemyśle, a poziom wykształcenia wzrósł kilkakrotnie. Jedna wyraźna różnica pozostała w religijności: przynależność do kościołów zadeklarowało w ostatnim spisie ludności 76\% Słowaków - w tym do katolickiego 62\%. Jest to wyraźny dowód, że twarda polityka ateistyczna władz komunistycznych w dawnej Czechosłowacji nie jest jedyną czy nawet główną przyczyną spadku liczby wierzących w Czechach. Polityka komunistów czechosłowackich była bowiem w obydwu częściach dawnej federacji taka sama, a pomimo tego na Słowacji pozostało pięciokrotnie więcej ludzi deklarujących przynależność do kościoła, aniżeli w Czechach.

Gospodarka Słowacji dziś tylko częściowo eksploatuje przedsiębiorstwa przemysłowe, powstałe na jej terytorium w okresie czechosłowackim. Były tu bowiem zlokalizowane zakłady zbrojeniowe (ze względów strategicznych, dalej od granicy zachodniej, uważanej wówczas za potencjalnie zagrożoną), które w latach 90. przeważnie upadły lub znacznie ograniczyły produkcję. Ograniczenia produkcji zbrojeniowej nastąpiły jeszcze w ostatnich latach wspólnego państwa, co było inicjowaną przez Czechów próbą 
odcięcia się od dziedzictwa komunizmu, ale wielu Słowaków do dziś uważa, że było to działanie z premedytacją na szkodę Słowaków.

Słowacki przemysł w ostatnich dwu dekadach wyspecjalizował się w produkcji samochodów. Rocznie wyprodukuje ich ok. miliona. Kolejno powstały tu zakłady znanych firm samochodowych, takich jak: Volkswagen w Bratysławie, PSA Peugeot-Citröen w Trnawie i koreańska Kia w Żylinie. Wiadomością roku 2015 było ogłoszenie rozpoczęcia budowy zakładu marki Jaguar - Land Rover, należącej do indyjskiego koncernu Tata Motors. Zakłady mają powstać w Nitrze. Słowacja stała się w ten sposób państwem produkującym najwięcej samochodów osobowych w przeliczeniu na liczbę mieszkańców - 171 samochodów na tysiąc mieszkańców (Hobbs 2009).

Rolnictwo było reprywatyzowane, ale tak samo jak w Czechach nie doprowadziło to do pełnego odrodzenia się warstwy chłopskiej, zniszczonej w okresie komunistycznym. Większość ziemi rolnej pozostała w rękach postkomunistycznych spółdzielni i kombinatów, które przetransformowały się na nowe spółdzielnie lub spółki wg nowego prawa handlowego (spółki z o.o. lub spółki akcyjne). Trzeba jednak przyznać, że prywatnych rolników gospodarujących samodzielnie jest na Słowacji więcej niż w Czechach. Gospodarują na prawie 40\% ziemi rolnej. Liczba zatrudnionych w sektorze rolniczym spadła z 13,5\% w roku 1990 do zaledwie $4 \%$ w chwili obecnej (2015).

Pomimo bardziej rolniczego charakteru gospodarki Słowacji, kraj ten jest daleko w tyle za średnią EU pod względem produkcji rolnej razem wziętej. W przeliczeniu na jednego mieszkańca, słowaccy rolnicy wyprodukowali w roku 2014 tylko 68\% średniej UE. Średnią europejską przewyższa tylko produkcja roślinna (zboża), a grubo poniżej średniej jest hodowla zwierząt oraz produkcja jarzyn i owoców.

Infrastruktura transportowa rozwija się wolniej ze względu na trudne warunki geomorfologiczne, ponieważ Słowacja jest krajem przeważnie górzystym. Autostrad jest $419 \mathrm{~km}$, dróg ekspresowych tylko $258 \mathrm{~km}$, ale są to tylko pojedyncze odcinki. Najdłuższy odcinek autostrady prowadzi z Bratysławy do Żyliny. Linii kolejowych jest 3623 km, w tym 1577 km zelektryfikowanych - wyraźnie mniej niż w Czechach, a na dodatek słabo wykorzystywane peryferyjne odcinki zostały $\mathrm{w}$ ostatnich latach zamknięte. Transport lotniczy też się nadmiernie nie rozwinął, ponieważ największe słowackie lotnisko w Bratysławie leży w cieniu dużego międzynarodowego lotniska w Wiedniu. Lotnisko Schwechat jest zlokalizowane dokładnie między Wiedniem a Bratysławą, w odległości ok. 20 $\mathrm{km}$ od stolicy Słowacji. To lotnisko jest więc bramą prowadzącą w świat dla Słowaków. Lotnisko w Bratysławie ma charakter lotniska zapasowego. Słowacja nie ma dziś własnych państwowych linii lotniczych. Próba 
utrzymania przy życiu przedsiębiorstwa Słowackie Linie Lotnicze trwała zaledwie kilkanaście lat (1995-2007). Ich upadek był wynikiem walki konkurencyjnej, spotęgowanej zwłaszcza po wejściu na rynek tanich przewoźników. Potwierdziła się teza, że przewoźnik narodowy kraju z $5 \mathrm{mln}$ mieszkańców ma niewielkie szanse przetrwania.

Podsumowując, Słowacja jest nadal w pewnym sensie „młodszym bratem" Czech, ale całkowicie już wyemancypowanym i niezależnym. W niektórych aspektach "młodszy brat" osiągnął nawet więcej od "starszego" - np. w kwestii waluty euro, którą Słowacja przyjęła już w roku 2009.

W kontekście konfliktowych, a nawet krwawych rozpadów Związku Sowieckiego i Jugosławii, podział Czechosłowacji nie był obciążony tak negatywnymi konsekwencjami. Na stosunki czesko-słowackie miał nawet korzystny wpływ (Ukielski 2007).

\section{Na co dziś warto zwrócić uwage}

Porównując Czechosłowację z roku 1985 z Czechami i Słowacją z roku 2015, nie można uniknąć oceny pozycji tych krajów wśród ich sąsiadów. Z dzisiejszego punktu widzenia najważniejsza jest pozycja w Unii Europejskiej. Porównanie można przeprowadzić, stosując metodę kontrafaktualną tzn. porównując rzeczywisty stan dzisiejszy z fikcyjnym, który by zaistniał, gdyby nie doszło do rozpadu. Jak wyglądałaby w tym kontekście dzisiejsza pozycja Czechosłowacji w Unii Europejskiej? Pozycję tę najlepiej oddaje liczba głosów w Radzie Unii Europejskiej oraz liczba posłów w Parlamencie Europejskim. Według systemu określania wagi każdego państwa członkowskiego w UE możemy założyć, że pozycja Czechosłowacji (15,7 mln mieszkańców) byłaby podobna do pozycji Holandii (16,8 mln mieszkańców). Wyniki przedstawiono w tab. 1.

Tabela 1. Pozycja Czech i Słowacji w Unii Europejskiej w porównaniu z fikcyjną pozycją Czechosłowacji

\begin{tabular}{|l|c|c|c|c|c|c|c|c|}
\hline \multicolumn{1}{|c|}{ Organ } & Czechy & $\%$ & Słowacja & $\%$ & $\mathrm{Cz}+\mathrm{Sk}$ & $\%$ & Czechosłowacja & $\%$ \\
\hline $\begin{array}{l}\text { Rada Unii } \\
\text { Europejskiej }\end{array}$ & 12 & 3,4 & 7 & 2,0 & 19 & 5,4 & 13 & 3,7 \\
\hline $\begin{array}{l}\text { Liczba posłów } \\
\text { w parlamencie } \\
\text { europejskim }\end{array}$ & 21 & 2,8 & 13 & 1,7 & 34 & 4,5 & 26 & 3,5 \\
\hline
\end{tabular}

Źródło: Dane o Parlamencie Europejskim - www.europarl.europa.eu; dane o Radzie Unii Europejskiej - www.consilium.europa.eu; dane fikcyjne o Czechosłowacji - obliczenia własne. 
Waga głosów obydwu krajów w głosowaniach przyjmowanych kwalifikowaną większością wynosi obecnie 5,4\%, podczas kiedy Czechosłowacji przysługiwałoby najwyżej 3,7\%. Ponieważ Czechy i Słowacja razem wzięte mają o ponad $1 \mathrm{mln}$ mniej mieszkańców, można oczekiwać, że waga jej głosów byłaby nawet jeszcze trochę mniejsza. Liczba czeskich i słowackich posłów do Parlamentu Europejskiego wynosi dziś 35, tj. 4,5\% z wszystkich posłów Europarlamentu. Jednolita Czechosłowacja, na podstawie analogii z Holandia, miałaby najwyżej 26 posłów, tzn. 3,5\%.

Ta arytmetyka pokazuje, że małe kraje Unii Europejskiej są z przyczyn politycznych nadreprezentowane, na tym Czesi i Słowacy - dzieląc się $-\mathrm{w}$ pewnym sensie skorzystali. Nie zmienia to jednak faktu ich geopolitycznego osłabienia, nie mówiąc o stracie „marki”, jaką Czechosłowacja niewątpliwie była. Pod tym względem najwięcej straciła Słowacja, ponieważ Czesi są nadal kojarzeni z Czechosłowacją ale Słowacy nie. Na dodatek Słowacja często jest mylona z jeszcze mniejszą Słowenią.

W tej sytuacji jedyną rozsądną polityką dla tak małych państw jest dbałość o poważanie wśród pozostałych członków UE. Słowacja ją stosuje, podczas kiedy Czesi w ostatnich latach demonstrują niejednokrotnie, że mogą sobie pozwolić na własne odrębne zdanie. Co będzie skuteczniejsze, okaże się w niedalekiej przyszłości.

\section{Geografia regionalna w stylu prof. Ludwika Straszewicza}

Przegląd zmian, które nastąpiły w ciągu ostatnich 30 lat na terenie byłej Czechosłowacji, a które znalazły się w tym artykule, bynajmniej nie jest wyczerpujący. Jego tekst składa się z wybranych elementów, które najlepiej pokazują to, co się na tym obszarze zmieniło. Gdyby tematem zajął się prof. Straszewicz lub którykolwiek z geografów regionalnych jego pokroju, napisałby prawdopodobnie obszerną monografię, w której znalazłyby się - oprócz wymienionych - liczne dodatkowe informacje, dane, statystyki i mapy. Tylko, kto by to wydał?

Jest prawie pewne, że dzisiejsze wydawnictwa, wyspecjalizowane $\mathrm{w}$ wydawaniu literatury naukowej - w tym geograficznej - nie byłyby chętne do opublikowania takiej książki. Okazuje się, że od czasów prof. Straszewicza paradygmat geografii jako nauki i nauki w ogóle zmienił się dość istotnie. Problemy regionalne analizowane są dziś z mniejszym akcentem na ich szczegółowy opis, a z większym na uchwycenie i ocenę głównych kierunków i tendencji rozwoju regionalnego. Warto wspomnieć, że pewne cechy takiego podejścia miały już teksty Ludwika Straszewicza, co jest tylko dowodem na to, że już wówczas był geografem bardzo nowoczesnym i intuicyjnie wyczuwał, w jakim kierunku nasza dyscyplina 
naukowa będzie się rozwijać. Przy jego kontaktach ze światem i znajomością języków trudno, żeby było inaczej. Należy pamiętać, że profesor robił swoje syntezy regionalne bez komputerów, internetu i baz danych. Dziś trudno to sobie nawet wyobrazić.

Musimy się jednak pogodzić z tym, że w dzisiejszej geografii nie ma miejsca na wydawanie podobnych monografii. I to nie tylko z powodu zmian w zainteresowaniach samych geografów, którzy opis regionu przestali uważać za wybitne dokonanie naukowe. Każdy, kto chce dziś dowiedzieć się czegoś o konkretnym regionie, od dłuższego czasu nie sięga już bowiem ani po monografię, ani nawet po atlas. Podłączy się do internetu. Sięgnie do Wikipedii, do stron rządu danego kraju czy też tamtejszego urzędu statystycznego oraz wejdzie na Google Maps czy inny serwer kartograficzny. Tam jest o wiele więcej informacji niż w monografiach, publikowanych przez geografów z generacji Ludwika Straszewicza. Szukanie właściwych informacji $w$ internecie jest jednak dość trudne i bardzo pracochłonne, ponieważ znajduje się tam, oprócz ważnych informacji, wiele „balastu": masa mało istotnych szczegółów, często też błędy i wypaczenia. Informacje $\mathrm{w}$ internecie mamy $\mathrm{w}$ nadmiarze, nie są tam tak przejrzyście ułożone, ani podane $\mathrm{z}$ taką kulturą języka, jak w monografiach prof. Straszewicza. Aby do nich dotrzeć, trzeba się dziś nieźle natrudzić

176 i wykazać się dobrą orientacją w temacie oraz wiedzą podobną do tej, jaką dysponował sam profesor. Dlatego można bez wątpienia wspomnieć dziś profesora nie tylko z nutką nostalgii, lecz także z uznaniem dla jego ówczesnych dokonań.

\section{Literatura}

Dane o Parlamencie Europejskim, www.europarl.europa.eu.

Dane o Radzie Unii Europejskiej, www.consilium.europa.eu.

Hobbs J. J. (2009), World Regional Geography, Cengage Learning, Belmont.

Gniazdowski M. (2008), Słowacja. Ciagłość i przyspieszenie, [w:] L. Jesień (red.), Zmiana i kontynuacja: Polityka europejska wybranych państw Unii Europejskiej, Polski Instytut Spraw Międzynarodowych, Warszawa.

Morawiec R. (2008), Republika Czeska. Pragmatyka obrony interesu narodowego, [w:] L. Jesień (red.), Zmiana i kontynuacja: Polityka europejska wybranych państw Unii Europejskiej, Polski Instytut Spraw Międzynarodowych, Warszawa.

Rumpel P., Siwek T., Slach O. (2014), Czy Ostrawa jest kurczacym się miastem?, [w:] T. Stryjakiewicz (red.), Kurczenie się miast w Europie Środkowo-Wschodniej, Bogucki Wyd. Naukowe, Poznań, s. 61-67.

Siwek T. (2002), Morawianie, „Sprawy Narodowościowe - Seria Nowa”, t. 11, nr 20, s. 125-137.

Siwek T. (2004), The Lack of Experience in Democratic Dialogue: Main Cause of Disintegration of Czechoslovakia at 1993, [w:] J. Wendt, F. Bente, V. Bodocan (eds.), Poland and Romania before Enlargement of European Union and NATO, IGU Political Geography Commission, Warszawa, s. 30-34. 
Czechy, Słowacja i Czechosłowacja - geografia regionalna dawniej i dziś

Siwek T. (2005), Laicisation Process in Czechia: Spatial Analysis, "Space - Society - Economy / Przestrzeń - Gospodarka - Społeczeństwo", No. 7: Religion in the Time of Changes, s. 227-233.

Straszewicz L. (1972), Francja, PWN, Warszawa.

Straszewicz L. (1977), Włochy, PWN, Warszawa.

Straszewicz L. (1982), Hiszpania, PWN, Warszawa.

Ukielski P. (2007), Aksamitny rozwód. Rola elit politycznych w procesie rozpadu Czechosłowacji, Instytut Jagielloński, Warszawa.

Wyniki spisu ludności z roku 2011, Czeski Urząd Statystyczny.

Wyniki spisu ludności z roku 2011, Słowacki Urząd Statystyczny.

Tadeusz Siwek, prof. dr hab., Katedra Geografii Społeczno-Ekonomicznej i Rozwoju Regionalnego, Uniwersytet w Ostrawie 